\title{
A HAGYOMÁNYOS CITOGENETIKA ÉS A FISH EGYMÁST JÓL KIEGÉSZÍTŐ VIZSGÁLATOK GYERMEKKORI AKUT LIMFOID LEUKÉMIÁBAN
}

\author{
Haltrich Irén, Csóka Monika, Kovács Gábor, Fekete György \\ Semmelweis Egyetem, II. sz. Gyermekgyógyászati Klinika, Budapest
}

\begin{abstract}
Gyermekkori akut limfoid leukémiában a citogenetikai vizsgálat eredménye független prognosztikai tényező, különböző rizikócsoportokba történö besorolási szempont; a terápiás szerekkel szembeni érzékenységet vagy rezisztenciát is befolyásolhatja. Jelen tanulmányunkban 30 újonnan diagnosztizált vagy recidivált leukémiás gyermek G-sávos kariotípusát valamint a TEL/AML1 és az ABL/BCR fúziós gén, a 16 (9p21) tumorszuppresszor gén és az MLL gén interfázis-fluoreszcens in situ hibridizáció (I-FISH) vizsgálatát értékeljük. G-sávos kariotípus-analizissel az esetek felében találtunk klonális kromoszómaelváltozást. Az elóbbi módszert I-FISH technikával kiegészítve, a betegek 70\%-ában azonosítottunk kórjóslati szempontból jelentős számbeli vagy szerkezeti ALL-specifikus eltérést. Hét betegnél (19\%) a hagyományos citogenetikai vizsgálat tárt fel olyan komplex szerkezeti eltérést, mely a célzott I-FISH vizsgálattal nem volt kimutatható. Az AML1 gén emelkedett kópiaszáma (30\%) összhangban volt a G-sávval azonosított hiperdiploid kariotípusok 21-es kromoszómát érintő számbeli eltéréseivel. Egy betegnél az AML1 gén 5-6 kópiáját azonosítottuk, egy másiknál a der(21)-esen volt látható az AML1 gén amplifikációja, miközben a homológ kromoszóma AML1 génje a TEL/AML1 fúzióban vett részt. A gyermekkori B-sejtes ALL jó prognosztikai értékú rejtett transzlokációját, a t(12;21)(p13;q22)-et négy betegnél azonosítottuk, egynél a TEL gén deléciójával társult. Egy másik betegnél a TEL deléciója volt az egyedüli anomália. A 9p21 tumorszuppresszor régió mikrodelécióját 8 betegnél (23\%) identifikáltuk, a G-sávos kariotípusban csak két betegnél volt detektálható a deléció. Egy betegnél a 9p21-deléció mellett Philadelphia kromoszómát és a 17-es kromoszóma monoszómiáját azonosítottuk. Az I-FISH és a hagyományos citogenetikai módszer együttes alkalmazása lehetóséget nyújt a citogenetikai kép részletesebb azonositására, a gyermekkori leukémiák prognózisának pontosabb megitélésére és így az egyénre szabott és hatásosabb terápia kiválasztására. Magyar Onkológia 52: 283-291, 2008
\end{abstract}

Kulcsszavak: akut limfoid leukémia, citogenetika, I-FISH

Primary genetic abnormalities of leukemia cells have important prognostic significance in childhood acute leukemia. In the last two years 30 newly diagnosed or recurrent childhood ALL bone marrow samples were analyzed for chromosomal abnormalities with conventional G-banding and interphase-fluorescence in situ hybridization (I-FISH) using probes to detect BCR/ABL fusions, cryptic TEL/AML1 and $M L L$ rearrangements and $16(9 p 21)$ tumor suppressor gene deletions. G-banded karyotype analysis found clonal chromosomal aberrations in 50\% of cases. With the use of complementary I-FISH techniques, ALL-specific structural and numerical changes could be identified in $70 \%$ of the patients. Nine cases $(30 \%)$ had subtle chromosomal aberrations with prognostic importance that had not been detected in G-banded analysis. Conventional G-banding yielded additional information (rare and complex structural aberrations) in 19\% of patients. The most common aberration (30\%) was AML1 copy number increase present in G-banded hyperdiploid karyotype as a chromosome 21 tetrasomy in the majority of cases; one case displayed 5-6 copies and in another case amplification of AML1 gene on der(21) was combined with TEL/AML1 fusion of the homologue AML1 gene and deletion of the remaining TEL allele. High hiperdiploidy was detected in 6 cases, in one patient with normal G-banding karyotype. TEL/AML1 fusion signals were identified in four patients. Deletion of 16 locus was found in eight cases $(23 \%)$, of which only two had cytogenetically visible rearrangements. G-banding in combination with I-FISH has produced major improvements in the sensitivity and accuracy of cytogenetic analysis of ALL patients and this method helps to achieve a more precise identification of different risk categories in order to choose the optimal treatment. Haltrich I, Csóka M, Kovács G, Fekete G. Cytogenetic and FISH findings are complementary in childhood ALL. Hungarian Oncology 52: 283-291, 2008

Keywords: acut lymphoblastic leukemia, cytogenetics, I-FISH
Közlésre érkezett: 2007. november 20.

Elfogadva:

2008. augusztus 26.

Levelezési cím:

Dr. Haltrich Irén

Semmelweis Egyetem, II. sz. Gyermekgyógyászati Klinika 1094 Budapest Tüzoltó utca 7-9. Telefon: (06-1) 215-1380 Fax: (06-1) 217-5770 E-mail: haltrich@gyer2.sote.hu

A jelen közlemény a GVOP 3.2.1-2004 -040381/3.0 müszerpályázat támogatásával készült. 


\section{BEVEZETÉS}

A pontos kockázatbecslés egyre nagyobb szerephez jut a gyermek- és serdülőkori akut limfoid leukémia (ALL) kezelésében, a rizikótényezőkön alapuló terápiás protokollok 5 éves eseménymentes túlélésre vonatkoztatott átlagos sikeressége a $80 \%$-ot is meghaladta (32, 40). A különböző rizikócsoportokba (alacsony - LR, közepes - MR, magas - HR) történő besorolás a klinikai adatok (immunfenotípus, életkor, nem, kezdeti fehérvérsejtszám), a prednisolon-válasz, valamint a leukémiás sejtek genetikai elváltozásai alapján történik (41). Ez utóbbi kivételes jelentőségű, mivel a citogenetikai eltérés független prognosztikai tényező és a különböző terápiás szerekkel szembeni érzékenységet vagy rezisztenciát is befolyásolhatja (31).

Az ALL-specifikus genetikai aberrációk több mint fele standard citogenetikai vizsgálattal kimutatható. A rejtett rendellenességek feltárásában a fluoreszcens in situ hibridizáció (FISH) (30) alapú molekuláris citogenetikai technikák bevezetése jelentett áttörést, mely lehetővé tette az alacsony sávszámú kromoszómák vagy az osztódásra nem bírható leukémiás sejtek rendellenességeinek célzott feltárását.

A Semmelweis Egyetem II. sz. Gyermekgyógyászati Klinika Citogenetikai Laboratóriumában, ALL iránydiagnózis esetén a WHO ajánlása alapján a gyermekek csontvelővizsgálatát - a hagyományos citogenetika mellett - FISH technikával is elvégezzük. Jelen tanulmányunkban 30 újonnan diagnosztizált vagy recidivált leukémiás gyermek G-sávos kariotípusát, valamint a TEL/AML1 és az ABL/BCR fúziós gén, a p16 (9p21) tumorszuppresszor gén és az MLL gén interfázis-fluoreszcens in situ hibridizációs (I-FISH) vizsgálatát értékeljük.

\section{VIZSGÁLT BETEGEK ÉS ALKALMAZOTT MÓDSZEREK}

\section{Vizsgált betegek}

A 27 új és három recidivált ALL-es beteget a Semmelweis Egyetem II. sz. Gyermekgyógyászati Klinikáján diagnosztizáltuk a klinikai, morfológiai, immunológiai és citogenetikai adatok alapján 2005 és 2006 között. A betegek a következő FAB (4) besorolást kapták: ALL-L1 (23 beteg), ALL-L2 (3 beteg), ALL-L1,2 (3 beteg), ALL-L3 ( 1 beteg) és ALL-recidíva ( 3 beteg). A 14 lány és 16 fiú ALL-es beteg életkora 2-től 16 éves korig terjedt, 7,4 év átlagéletkorral. Hat beteg T-sejtes, 24 B-sejtes (22 preB-ALL és két érett B-ALL) immunfenotípusú volt. A betegek legfontosabb klinikai adatait az 1. táblázatban foglaltuk össze.

\section{Hagyományos citogenetika}

A diagnózis idején 24 órás stimulálatlan tenyésztést végeztünk a csontvelői sejtekből standard technikával (8). GTG sávozás (Giemsa-sáv tripszinemésztéssel és
Giemsa-festéssel) után az értékelést Cohu CCD kamerával (Herrsching, Németország) felszerelt mikroszkóppal (Axioskop 2 Mot Plus, Carl Zeiss MicroImaging $\mathrm{GmbH}$, Németország) végeztük. A metafázis képeket PSI Cytovision 3.6 (Scientific Systems, UK) szoftverrel dolgoztuk fel. A kariotípust a nemzetközileg elfogadott ISCN 2005-ös nomenklatúra (25) alapján írtuk le 20-25 metafázis alapján.

\section{FISH vizsgálatok}

A FISH vizsgálatokat csontvelői sejtszuszpenzióból a diagnóziskor végeztük el. Az LSI TEL/AML1 ES, DC (extra szignálú dupla color), az LSI BCR/ABL DC, DF (dupla color és fúzió) transzlokációs próbákat, az LSI p16 (9p21) SpectrumOrange/CEP9 SpectrumGreen deléciós próbát valamint az LSI MLL DC, BAR „hasadt gén" próbát a Vysis cégtől (Abbot GmbH and Company, KG, Németország) szereztük be. A TEL/AML1 és a BCR/ ABL fúziós próbák alkalmasak a 12p13, a 21q22-es, illetve a 22q11 és 9q34 régiók kópiaszámának azonosítására, valamint következtetni lehet az érintett kromoszómák aneuploidiájára is. Az LSI p16 (9p21)/CEP9-es próba 9pdeléciót és a 9-es kromoszóma számbeli eltéréseit identifikálja. Az LSI MLL szonda a „mixed lineage leukémia” gén hasadását azonosítja. Egyes betegeknél kiegészítő FISH vizsgálatokat végeztünk Iso 17q (MPO/p53), X kromoszóma Alpha satellite DXZ1, MYC/IGH t(8;14) (QBIOgene, Franciaország) és CEP12 (D12Z3) Spectrum Green (Vysis) próbákkal. A FISH vizsgálatokat kisebb módosításokkal (9) a cég ajánlásai alapján végeztük el.

Az eredményeket Hamamatsu C 4800 CCD kamerával (Herrsching, Németország) felszerelt fluoreszcens mikroszkóppal (Axioskop 2 Mot Plus, Carl Zeiss MicroImaging $\mathrm{GmbH}$, Németország) értékeltük. A FISH képeket Cytovision 3.6 (Applied Imaging, UK) szoftverrel dolgoztuk fel. A FISH jeleket 100-200 interfázisos sejtmagban számoltuk meg, metafázisok értékelésére csak akkor került sor, ha azok rendelkezésre álltak a hibridizációs területen.

\section{EREDMÉNYEK}

$\mathrm{Az}$ 1. táblázatban a vizsgált 30 gyermekkori ALL-es beteg citogenetikai és FISH vizsgálati eredményét foglaltuk össze. Az esetek 93\%-ában értékelhető metafázisokat nyertünk. Rutin citogenetikai (G-sávos módszer) vizsgálat során a betegek felében, ezt molekuláris citogenetikai vizsgálattal kiegészítve a gyermekek 70\%ában azonosítottunk klonális aberrációt.

A 15 kóros kariotípusú esetből 6 hiperdiploid, 5 pszeudodiploid, egy közel tetraploid és egy hipodiploid volt. Gyermekkori ALL-re jellemző specifikus hiperdiploid B kariotípust 4 esetben (1. táblázat, 11., 17., 20. és 29. beteg) azonosítottunk hagyományos citogenetikával. A hiperdiplod B betegek kromoszómamintázata nem volt egységes, de mindegyikben három vagy háromnál 
1. táblázat. A vizsgált ALL-es betegek klinikai adatai, citogenetikai és interfázis-FISH eredményei. A FISH vizsgálatokat a TEL/AML1 fúziós génre, a 9-es centromérára, a p16 (9p21) régióra, a Philadelphia kromoszómára és az MLL génre vonatkozóan összesitettük.

\begin{tabular}{|c|c|c|c|c|c|c|c|c|c|}
\hline Eset & $\begin{array}{l}\text { Kor/ } \\
\text { nem }\end{array}$ & $\begin{array}{l}\text { FAB } \\
\text { csoport }\end{array}$ & $\begin{array}{l}\text { Immun- } \\
\text { feno- } \\
\text { típus }\end{array}$ & $\begin{array}{l}\text { Fvs. } \\
\text { szám } \\
\text { x109L }\end{array}$ & Citogenetikai vizsgálat eredménye & TEL/AML1 & $\begin{array}{l}\text { p16 (9p21) } \\
\text { /CEP9 }\end{array}$ & $\begin{array}{l}\mathrm{ABL} / \\
\mathrm{BCR}\end{array}$ & MLL \\
\hline 1. & $4 / \mathrm{M}$ & L1,2-LR & PreB & 3,6 & sikertelen & AML1++++ & - & - & - \\
\hline 2. & $5 / \mathrm{M}$ & L1-LR & PreB & 69,9 & 47,XY,del(9)(p13),+21[10]/46,XY[10] & AML1+++ & $\operatorname{del}(9 p 21)$ & - & - \\
\hline 3. & $14 / \mathrm{M}$ & L1-HR & T-ALL & 35,6 & $46, \mathrm{XY}, \operatorname{del}(9)(\mathrm{p} 11)[10] / 46, \mathrm{XY}[12]]$ & normális & $\operatorname{del}(9 p 21)$ & - & - \\
\hline 4. & $2 / \mathrm{F}$ & L2-MR & PreB & 44,5 & $46, X X[20]$ & normális & $\operatorname{del}(9 \mathrm{p} 21)$ & - & - \\
\hline 5. & $16 / \mathrm{F}$ & L1-HR & T-ALL & 72 & $46, \mathrm{XX}, \mathrm{t}(8 ; 14)(\mathrm{q} 24 ; \mathrm{q} 11)[12] / 46, \mathrm{XX}[8]$ & normális & normális & neg & - \\
\hline 6. & $3 / \mathrm{F}$ & L1-MR & PreB & 46 & $46, X X[21]$ & normális & normális & - & - \\
\hline 7. & $3 / \mathrm{F}$ & L1-MR & PreB & 64,2 & $46, X X[19], 48, X X,+$ mar1, mar2[2] & fúzió & normális & - & - \\
\hline 8. & $6 / \mathrm{M}$ & L1-HR & T-ALL & 37,1 & $46, X Y[25]$ & normális & normális & neg & neg \\
\hline 9. & $4 / \mathrm{F}$ & L1-SR & PreB & 12,4 & $46, X X[20]$ & fúzió & normális & - & - \\
\hline 10. & $9 / \mathrm{M}$ & $\begin{array}{l}\text { ALL-rec } \\
\text { L1 }\end{array}$ & PreB & 7,8 & $46, X Y[23]$ & AML1+++/+++++ & normális & neg & neg \\
\hline 11. & $10 / \mathrm{M}$ & L1--MR & PreB & 24,1 & $\begin{array}{l}\text { 51-52,XY,+X,+6,i(10)(q10),+14,+15+21,+21,+mar } \\
{[\mathrm{cp} 5] / 46, \mathrm{XY}[18]}\end{array}$ & $\begin{array}{l}\text { AML1++++ } \\
{[80 / 100]}\end{array}$ & normális & neg & neg \\
\hline 12. & $2 / \mathrm{M}$ & L3 & Érett B & & $46, \mathrm{XY}, \mathrm{t}(8 ; 14)(\mathrm{q} 24 ; \mathrm{q} 32)[23] / 46, \mathrm{XY}[2]$ & normális & normális & - & - \\
\hline 13. & $10 / \mathrm{F}$ & L1-HR & T-ALL & 298,2 & $46, X X[20]$ & normális & normális & neg & neg \\
\hline 14. & $9 / \mathrm{F}$ & L1-MR & PreB & 29,1 & $46, X X[22]$ & fúzió & $\operatorname{del}(9 \mathrm{p} 21)$ & neg & neg \\
\hline 15. & $6 / \mathrm{M}$ & L1-MR & PreB & 2,6 & $47, X Y, t(1 ; 19)(q 23 ; p 13),+5[19] / 46, X Y[5]$ & normális & normális & neg & neg \\
\hline 16. & $10 / \mathrm{F}$ & L1-MR & PreB & 1,66 & $\begin{array}{l}\text { 1p34,4q21,8q24,12q13,14q32töréspontokat érintő } \\
\text { komplex átrendeződés,del(3)(q21),del(17)p(13) }\end{array}$ & normális & normális & neg & neg \\
\hline 17. & $3 / \mathrm{M}$ & L1-MR & PreB & 37,7 & $\begin{array}{l}55, X Y,+X,+6,+10,+13,+14,+17,+18,+21,+21[10] / \\
46, X Y[10]\end{array}$ & AML1++++ & normális & ABL++++ & neg \\
\hline 18. & $4 / \mathrm{M}$ & L1-MR & PreB & 40,7 & $46, \mathrm{XY}[26]$ & normális & normális & neg & neg \\
\hline 19. & $13 / \mathrm{M}$ & L1-HR & T-ALL & 395 & $46, X Y[20] / 47, X Y,+\operatorname{mar}[2]$ & normális & $\operatorname{del}(9 \mathrm{p} 21)$ & neg & neg \\
\hline 20. & $3 / \mathrm{F}$ & L1-SR & PreB & 20 & $\begin{array}{l}57, \mathrm{XX},+\mathrm{X},+4,+6,++9,+14,+17,+18,+19,+21, \\
+21[10] / 46, \mathrm{XY}[10]\end{array}$ & AML1++++ & $\begin{array}{l}\text { CEP9/ } \\
\text { p16+++ }\end{array}$ & ABL+++ & neg \\
\hline 21. & $7 / \mathrm{M}$ & $\begin{array}{l}\text { ALL-rec } \\
\text { L1,2 }\end{array}$ & PreB & $34,2-$ & 46,XY,der(21)add(21)(q22) & $\begin{array}{l}\text { fúzió; } \\
\text { TEL deléció } \\
\text { AML1++++ }\end{array}$ & normális & neg & neg \\
\hline 22. & $4 / \mathrm{M}$ & L1,2-SR & T-ALL & 5,6 & $46, X Y[21]$ & normális & normális & neg & neg \\
\hline 23. & $7 / \mathrm{F}$ & L1-MR & PreB & 6,1 & sikertelen & normális & normális & neg & neg \\
\hline 24. & $7 / \mathrm{M}$ & L1-HR & PreB & 49,1 & $45, \mathrm{XY}, \operatorname{inv}(9)(\mathrm{p} 11 \mathrm{q} 23) \mathrm{c}, \mathrm{t}(9 ; 22)(\mathrm{q} 34 ; \mathrm{q} 11),-17[21]$ & normális & $\operatorname{del}(9 \mathrm{p} 21)$ & fúzió & neg \\
\hline 25. & $11 / \mathrm{F}$ & $\begin{array}{l}\text { ALL-rec } \\
\text { L1 }\end{array}$ & PreB & 4,1 & $46, X X,[21]$ & normális & normális & neg & neg \\
\hline 26. & $11 / \mathrm{F}$ & L1-HR & PreB & 49,1 & $46, X X[20]$ & TEL deléció & normális & neg & neg \\
\hline 27. & $11 / \mathrm{F}$ & L1-MR & PreB & 20,6 & $46, X X[21]$ & normális & normális & neg & neg \\
\hline 28. & $10 / \mathrm{F}$ & L1-MR & PreB & 10,5 & $46, X X[25]$ & normális & normális & neg & neg \\
\hline 29. & $6 / \mathrm{M}$ & L2-SR & PreB & 3,6 & $\begin{array}{l}56-58, \mathrm{XY},+\mathrm{X},+4,+5,+6,+8,+10,+12,+15,+17,+18, \\
+21,+21,+22[\mathrm{cp} 7] / 46, \mathrm{XY}[14]\end{array}$ & $\begin{array}{l}\text { AML1++++ } \\
\text { TEL+++ }\end{array}$ & $\operatorname{del}(9 \mathrm{p} 21)$ & BCR+++ & neg \\
\hline 30. & $11 / \mathrm{M}$ & L2-MR & PreB & 2,7 & $\begin{array}{l}\text { Közel tetraploid, szerkezeti elváltozással (iso(9q). } \\
\text { Modális kromoszómaszám } 84\end{array}$ & $\begin{array}{l}\text { AML1++++++/ } \\
\text { TEL+++ }\end{array}$ & $\operatorname{del}(9 \mathrm{p} 21)$ & $\begin{array}{l}\mathrm{BCR}+++ \\
\mathrm{ABL}+++\end{array}$ & neg \\
\hline
\end{tabular}




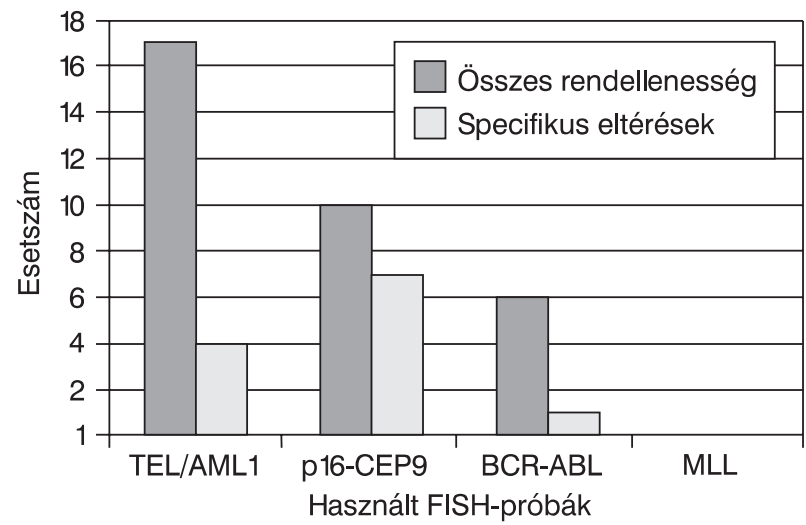

1. ábra. Az I-FISH vizsgálati eredmények grafikus ábrázolása. A sötét színü oszlopok a nevezett próbákkal végzett hibridizációval feltárt rendellenességek számát, a világos színü oszlopok a keresett specifikus eltérések számát jelölik több 21-es kromoszómát, számfeletti X és 6-os kromoszómát azonosítottunk. A hiperdiploid A betegeknél (2. és 15. eset) a 21-es, az 5-ös volt a számfeletti kromoszóma. Egy betegnél (30.) a modális kromoszómaszám 84 volt, amely a leukémiákban ritkán előforduló, közel tetraploid kariotípusnak felel meg. A hipodiploiditást a 17-es monoszómia okozta (24. beteg). A G-sávos kromoszómákon látható ALL-specifikus transzlokációk (5., 12., 15. és 24. beteg) a következők voltak: $t(8 ; 14)(q 24 ; q 11)$, $\mathrm{t}(8 ; 14)(\mathrm{q} 24 ; \mathrm{q} 32), \mathrm{t}(1 ; 19)(\mathrm{q} 23 ; \mathrm{p} 13)$ és a $\mathrm{t}(9 ; 22)(\mathrm{q} 34 ; \mathrm{q11})$. Több kromoszómát érintő komplex átrendeződést három betegnél azonosítottunk (11., 16. és 30. eset).

A FISH-próbákkal végzett vizsgálati eredmények az 1. ábrán láthatók. A vizsgált betegeknél az AML1 gén emelkedett kópiaszáma volt a leggyakoribb rendellenesség (30\%) (2.A ábra), mely összhangban volt a
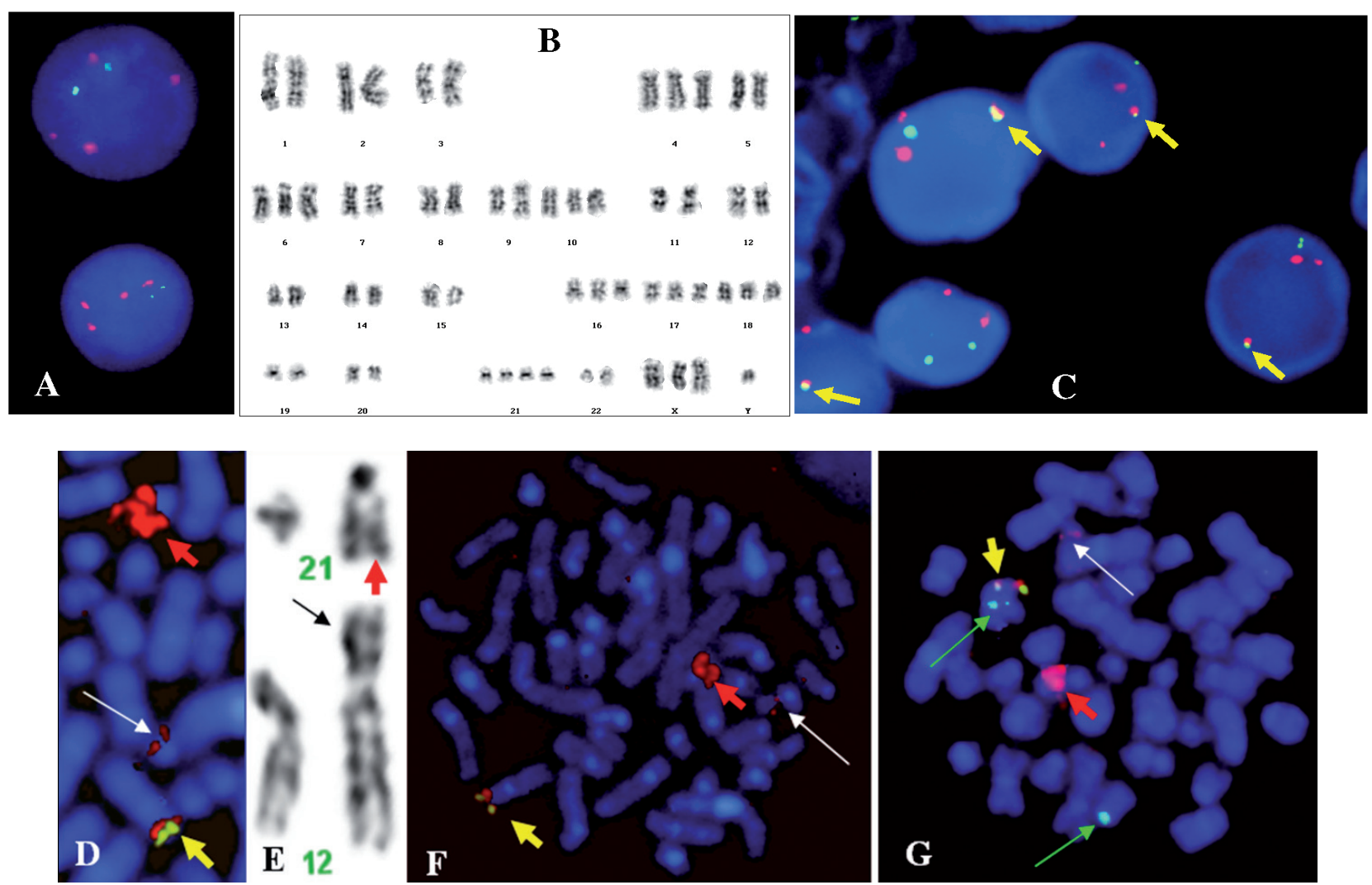

2. ábra. A TEL/AML1 FISH-próbával feltárt rendellenességek illusztrálása. A. Az interfázisos magok 25\%-ában látható AML1 gén 4 különálló kópiája (piros jelek) irányított a 23 G-sávos metafázis alapján meghatározott normális kariotípus átértékelésére (10. beteg). Nagyobb számú osztódó sejt analizálásával és a kóros metafázisok célzott keresésével igazolódott a hiperdiploid B kariotípus (B) klonális jelenléte az 5 év után recidivált

betegnél. C. A TEL/AML1 fúziós gén zöld-piros FISH-mintázatát sárga nyíllal jelöltük. A normális vad típusú AML1 allélt egy nagyobb, a reziduálisat egy kisebb piros jel azonosítja. A szabad zöld jel az ép 12-es kromoszóma TEL génjét identifikálja. A képen egy normális mintázatú (nyíl nélküli) sejtmag is látható (9. beteg). A 21. betegnél (D,E,F,G) a G-sávos 21-es kromoszómán látható többletet ( $E$ ábra, fenn) a FISH vizsgálat az AML1 gén amplifikációjaként azonositotta (piros nyíl). A sárga nyillal a TEL/AML1 fúziós gént jelöltük (zöld-piros jel). A derivátum 21-esen (fehér nyíl) a transzlokációban résztvevő piros AML1 gén "maradéka” látható. A transzlokációban részt nem vevő, homológ 12-es kromoszóma TEL génje elveszett (a metafázis FISH-mintázatából hiányzik a második zöld jel). A G ábrán a 12-es kromoszóma zöld szinü centroméra-specifikus (CEP12) és a TEL/AML1 próba együttes hibridizációja szokatlan FISH-mintázatot igazol: a fúziós gén nem a 21-es kromoszómán látható, hanem a zöld nyíllal jelölt 12-es kromoszóma egyikén

G-sávos kariotípus 21-es kromoszóma tri-, tetra-, illetve pentaszómiájával. A 10. betegnél 23 metafázis értékelése normális kariotípust eredményezett és csak az interfázisos magok 25\%-ában látható 3-5 különálló AML1 szignál vezetett a célzottan keresett hiperdip- loid B metafázisok utólagos azonosításához (2.B ábra). A betegség diagnózisakor hiperdiploid B kariotípust azonosítottunk. Az öt évvel későbbi relapszus idején a hiperdiploid B kariotípusban szerkezeti elváltozás is látható volt. A 30. betegnél az AML1 gén hat kópiája 

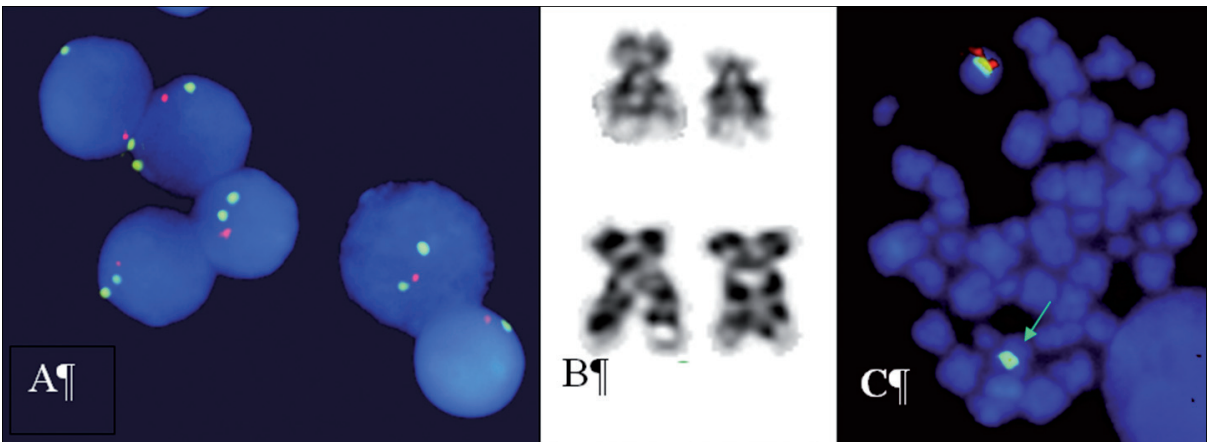

3. ábra. A 9p21 tumorszuppresszor deléciós régió vizsgálatának illusztrációja. A. A p16/CEP9 dual color próbával végzett FISH vizsgálat normális 9-es kromoszóma centromérát (2 zöld jel) és a p16 tumorszuppresszor régió delécióját (1 piros jel) azonositotta az interfázisos magokon a normális kariotípusú 14. betegnél. A p16 tumorszuppresszor régió vesztése G-sávval csak akkor volt detektálható, ha a 9-es kromoszóma rövid karjának egy nagyobb szegmentje hiányzott (B fent, 3. beteg). A 4. beteg G-sávos 9-es kromoszómáin (B lent) nem érzékelhető a deléció, a 9p21-régióvesztést csak a célzott FISH vizsgálat mutatta ki (C, zöld nyíl)

közel tetraploid kariotípussal társult. A gyermekkori ALL-re jellemző leggyakoribb rejtett rendellenességet, a t(12;21)-es transzlokációt 4 betegnél azonosítottuk (7., 9., 14. és 21.) (2.C ábra). A 12-es kromoszóma egyik TEL génjének delécióját két betegnél detektáltuk (21. és 26.), egyiknél ez az egyedüli anomália volt. A 21. betegnél az AML1 gén amplifikációját detektáltuk a derivátum 21-es kromoszómán, a homológ AML1 gén a t(12;21)-es transzlokációban vett részt és a homológ 12-es kromoszóma TEL génje deletálódott (2.D-Fábra).

Említésre méltó, hogy a TEL/AML1 fúziós termék nem a megszokott helyén, a derivátum 21-esen volt látható, hanem a derivátum 12-es kromoszómára transzlokálódott, melyet 12-es centroméra és TEL/AML1 fúziós próba együttes hibridizációjával igazoltunk (2.Gábra). A G-sávos derivátum 21-es nagy akrocentrikus kromoszómaformát mutatott (2.E ábrán piros nyíllal jelölve), csak a specifikus FISH-próba azonosította az AML1 gén tandem jellegű ismétlődését, sejtenként változó, nehezen meghatározható kópiaszámmal (2.D,F,G ábrán piros nyíllal jelölve).

G-sávval azonosítható, INK4 lókuszt érintő 9p-deléció két betegnél fordult elő, a másik 6 esetben csak a FISH vizsgálat identifikálta a rejtett deléciót (3. ábra). Két betegnél (3. és 4.) volt egyedüli anomália, kettőnél (2. és 29.) hiperdiplod, egynél (30. eset) közel tetraploid kariotípussal, illetve egynél (14.) a TEL/AML1 fúziós génnel társult. A 24 . betegnél a konstitucionális pericentrikus inverziós 9-es kromoszóma 9p21-delécióját azonosítottuk, a homológ 9-es pedig a t(9;22)-transzlokációban vett részt. Ennél a betegnél a Philadelphia kromoszómához a 17-es kromoszóma monoszómiája is társult (4. ábra).

A FISH-próbákkal végzett hibridizáció 9 betegnél azonosított egy vagy több szám feletti kromoszómát. $\mathrm{Az}$ 1. betegnél nem sikerült a citogenetikai véleményhez elegendő metafázist összegyűjteni. A talált négy metafázisból egy 58-as kromoszómaszámú volt. Ennél a fiú betegnél az interfázis-FISH vizsgálattal azonosított négy különálló AML1-kópia valószínüsítette a hiperdiploid kariotípust, melyet az X-centroméra-próbával elvégzett kiegészítő FISH vizsgálat (két X-centroméra jelenléte) is megerősített. A 10. betegnél a G-sávos ka-

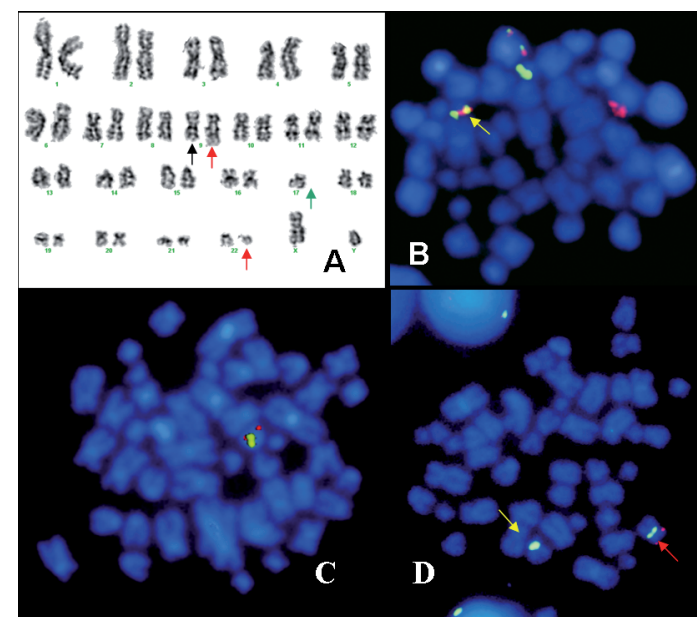

4. ábra. A 24. beteg komplex citogenetikai eltérésének vizsgálata. A G-sávos kariotípizálás (A) a 9;22-es transzlokáció (piros nyíl) mellett a 17-es monoszómiát (zöld nyíl) és a 9-es kromoszóma inverzióját (fekete nyíl) azonosította. A célzott FISH vizsgálat igazolta a Philadelphia kromoszómát ( $B$, sárga nyíl), a p53 tumorszuppresszor régió vesztését (C, egy zöld 17p12-p13 lókusz jel) és azonosította a p16 rejtett delécióját $(D$, két zöld centroméra és egy piros p16 lókusz jel, a deletált 9-es sárga, a normális piros nyíllal jelölve)

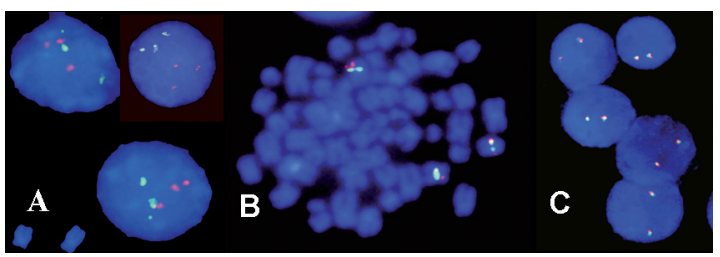

5. ábra. A lókuszspecifikus próbákkal végzett hibridizáció a kevés számú vagy rossz minöségü metafázisok esetén is egyértelmüvé tette a jó prognózisú hiperdiploid kariotípust vagy metafázisok hiányában kizárta a rossz prognózisú MLL gén érintettségét. A 20. betegnél 3 piros $A B L-, 3$ zöld BCR-jel (A), 3 zöld 9-es centroméra, 3 piros $p 16$ (B) 9-es és 22-es triszómiát igazol. A 23. beteg esetében (C) az interfázisos magokban ép MLL gén látható

riotípus normálisnak bizonyult és csak a nagyobb számú interfázisban lévő magok FISH vizsgálata hívta fel a figyelmet a visszatérő hiperdiploiditásra. A vizsgált betegeknél MLL gént érintő rendellenességet nem találtunk (5. ábra). 


\section{MEGBESZÉLÉS}

Célunk a vizsgált 30 leukémiás gyermeknél a kezelés és a prognózis szempontjából kulcsfontosságú specifikus citogenetikai eltérések kimutatása volt. A sikeres tenyésztések ellenére a hagyományos citogenetikai módszerrel csak a betegek felében sikerült kromoszómaaberrációt kimutatni. Ennek egyik oka az lehet, hogy az akut limfoid leukémiás csontvelőtenyészet általában nehezen sávozható, szegényes morfológiájú kromoszómákat eredményez. Különösen a hiperdiploid metafázisokra jellemző az átlag alatti technikai minőség. Előfordulhat, hogy „in vitro” környezetben csak a normális sejtek osztódnak, esetleg csak a szép, „megbízható” metafázisok „vadászásával” éppen a kóros osztódások kimaradnak az értékelésből. Másik ok az, hogy a hagyományos citogenetika nem elég érzékeny módszer bizonyos rejtett rendellenességek kimutatatására. A G-sávos technikával nem azonosítható aberráció például a t(12;21)-es transzlokáció, melynél közel azonos nagyságú és mintázatú kromoszómaszegmensek cserélődnek ki az érintett kromoszómák között, a 9p21-es mikrodeléció vagy az MLL gén bizonyos kromoszómapartnerekkel történő fúziója. A hagyományos és a molekuláris citogenetika kombinálásával a betegek csaknem háromnegyedénél sikerült ALL-specifikus eltérést azonosítani. Az I-FISH vizsgálat a betegek 30\%ában tárt fel a prognózis szempontjából jelentős rejtett kromoszóma-rendellenességet. A G-sávos kariotipizálással a betegek 19\%-ában jutottunk többletinformációhoz. Az I-FISH gyors és érzékeny módszer, mely lehetővé teszi az osztódó és nem osztódó sejtek egyidejű értékelését és ezáltal a normális és kóros sejtfrakciók arányainak feltérképezését A G-sávos kariotípus az összkép mellett kiindulópontot nyújtott a célzott FISH vizsgálatokhoz is.

A vizsgált betegcsoportban a gyermekkori ALL-re jellemző, jó prognosztikai értékű masszív hiperdiploiditás a nemzetközi adatokkal megegyező arányban (27\%) fordult elő (31), és egy beteg kivételével diagnosztizálható volt hagyományos citogenetikai vizsgálattal. A hiperdiploid B-re jellemző 8 kromoszóma non-random triszómiája, melyek gyakorisági sorrendben a következők: 21, X, 14, 6, 18, 4, 17, 10 (16). A hiperdiploid B betegek kariotípusa összhangban volt ezzel a sajátságos kromoszómamintázattal. A hiperdiploid B kariotípushoz „prekurzor" B immunfenotípus, a CD10 common ALL antigén expressziója, kettőtől tíz évig terjedő életkor, alacsony fehérvérsejtszám és alacsony szérum-laktátdehidrogenáz-szint társul. Nagyszámú B-sejtes, hiperdiploid B kariotípusú gyermekkori ALL eset statisztikai értékelése alapján a jó prognosztikai hatás inkább bizonyos ",jó" triszómiákkal áll összefüggésben $(27,46)$, mint önmagában az emelkedett kromoszómaszámmal. Bizonyos munkacsoportok a 4-es, 10-es, 17-es $(12,47)$ triszómia együttes előfordulásánál számoltak be kiemelkedően jó terápiás sikerről, a legpozitívabb prediktív értéket (15) a 10-es triszómia esetében figyelték meg.
A 47 és 51 közötti hiperdiploid A kariotípusnak közepes a prognosztikai értéke, nincsenek jellegzetesen társuló ,jó" klinikai értékei és a kromoszómatöbbletmintázat sem annyira jellemző, mint a hiperdiploid B kariotípusnál. A 15. betegnél ALL-ben rendkívül ritka, rossz prognosztikai értékü 5-ös triszómiát (13) a t(1;19)es transzlokációt hordozó klónban azonosítottuk.

Mindkét hiperdiploid csoportra jellemző a 21-es kromoszóma kópiaszám-növekedése, mely az általunk vizsgált hiperdiploid betegek $90 \%$-ában is megfigyelhető volt. Éppen ezért a 21-es kromoszóma AML1 génjének kópiaszáma révén a t(12;21)-es transzlokációs próba kiválóan alkalmas a hiperdiploiditás azonosítására, mivel nagyszámú interfázisos magban történő megszámolásával lehetőséget nyújt az in vitro körülmények között nem osztódó populációk feltérképezésére.

A hiperdiploid kariotípus átlagosnál jobb prognózisát a 21-es kromoszómán lévő, methotrexat-transzportert kódoló gén emelkedett dózisával is összefüggésbe hozták (31). A fokozott génexpresszió lehetővé teszi nagyobb mennyiségü methotrexat felhalmozódását a leukémiás blasztokban.

Klinikánkon a hiperdiploid betegcsoport alacsony vagy közepes rizikójú besorolásnak megfelelő terápiában részesült, valamennyien remisszióban vannak. A 10. beteg a recidíva utáni első remisszióban sikeres testvér-donoros transzplantáción esett át.

A több mint 80 kromoszómával jellemezhető „közel tetraploid" kariotípus a gyermekkori ALL-ek 1\%-ában fordul elő. Rutin citogenetikával nehéz diagnosztizálni, mivel a mitózisok a rövid sejttenyészetekben gyakran előforduló, gyenge morfológiájú poliploid osztódásokra emlékeztetnek, tenyésztési „mütermékeknek” tünhetnek. A 30. betegnél az I-FISH vizsgálat a magok 75\%ában igazolta a TEL, BCR, ABL és AML1 gének emelkedett kópiaszámát, ami összhangban volt a metafázisokban látható kromoszómaszámmal. Bár biológiailag a közel-tetraploiditás különbözik a hiperdiploiditástól, a retrospektív tanulmányok alapján (34) úgy tünik, hogy a B-immunfenotípusú betegek hozzájuk hasonlóan jó prognózisúak és az alacsony rizikócsoportnak megfelelő kezeléssel gyógyíthatók. A közel-tetraploid kariotípusú beteg klinikai értékei a hiperdiploid B betegcsoporténál rosszabbak voltak $\left(2,7 \times 10^{9} \mathrm{~L}\right.$ fehérvérsejtszám, magasabb életkor), a G-sávos kariotípusban klonális szerkezetelváltozás is látható volt, az I-FISH vizsgálat 9p21-deléciót azonosított. A beteg közepes rizikójú csoportnak megfelelő terápiával jelenleg remisszióban van.

A gyermekkori B-sejtes ALL leggyakoribb rejtett transzlokációját, a t(12;21)-et a betegek 13\%-ában azonosítottuk. Ez az arány megegyezik néhány nagy esetszámot átfogó tanulmányéval (1), de a 20-25\%-os előfordulási gyakoriság az általánosabb (10, 17, 22, 39). A transzlokációban a 21q22 régióban térképezett a Core binding factor $\alpha$ (CBFA2) néven is ismert akut myeloid leukemia1 (AML1) nevü gén, valamint a 12p22 régióban azonosított „ETS-like gene” (ETV6) vagy TEL gén 
vesz részt. A keletkező hibrid génben a TEL promoter régió és helix-loop-helix domén kapcsolódik az AML1 gén DNS-kötő és transzaktivációs doménjéhez. A TEL transzkripciós modulátor, az AML1 gén a $\mathrm{CBF} \alpha-\mathrm{CBF} \beta$ transzkripciós komplex „ $\alpha$ " alegységét kódolja és számos vérképzéssel kapcsolatos gén transzkripciós aktivátora. A fúziós protein az AML1-target gének rendellenes szabályozásával váltja ki a leukémiás folyamatot. Ez a nemrég azonosított (38) transzlokáció általában kedvező életkorral és klinikai jellemzőkkel társuló, jó prognosztikai értékü elváltozás (45). Az első tanulmányok a TEL/AML1-pozitív betegek tartósabb komplett remissziójáról (56 vs. 26 hónap), de a késői relapszus veszélyéről számoltak be $(42,43)$. Hosszabb követésről szóló átfogó tanulmányok azonban csak az utóbbi években születtek. A retrospektív tanulmányok alapján a TEL/AML1-pozitív gyermekek relapszusmentes túlélése függ a rizikócsoportokba történő besorolási szempontoktól és az alkalmazott terápiás protokolltól (21). A TEL/AML1-pozitív limfoblasztok rendkívül érzékenyek az L-aszparaginázra, de jól reagálnak a szteroidokra és a vincristinre is $(19,36)$. Azok a TEL/AML1pozitív gyermekek, akiket olyan terápiás protokoll szerint kezeltek, mely az intenzifikációs kezelés alatt több L-aszparaginázt tartalmazott, elérték a 97\%-os ötéves össztúlélési rátát (20). A transzlokációhoz gyakran társul a homológ TEL gén deléciója, melynek funkcióvesztése a leukémiás transzformáció folyamatában játszhat szerepet (48), a terápia sikerességét lényegesen nem befolyásolja (33). A TEL-deléció egy betegnél - aki jelenleg remisszióban van - egyedüli anomália volt, a másik betegnél negatív prognosztikai hatású elváltozásokkal társult (a 26., illetve a 21. betegnél).

Egy TEL/AML1 fúziós gént hordozó betegnél p16deléciót is azonosítottunk (14. eset), eddig három ilyen esetről jelent meg irodalmi közlés (1, 2, 29). A p16 tumorszuppresszor gén hiánya apoptózisgátló és kemorezisztenciát kiváltó hatásával mindenképpen csökkenti a TEL/AML1-transzlokáció pozitív prognosztikai hatását (29).

A TEL/AML1-pozitív betegek, egy kivételével, ez idáig teljes remisszióban vannak. A 21. beteget elveszítettük. Ennél a betegnél a t(12;21)-es transzlokáció sem volt szokványos, mivel a TEL/AML1 fúziós termék a 12-es kromoszóma rövid karjának terminális végére transzlokálódott és a transzlokációban résztvevő gének homológjai is érintettek voltak. Az egyik 12-es kromoszóma TEL génje és az egyik 21-es kromoszóma AML1 génje a TEL-AML1-fúzióban vett részt, miközben a homológ TEL gén deletálódott és a homológ 21-es AML1 gén amplifikálódott a derivátum 21-esen. A 21-es intrakromoszomális amplifikáció (iAMP21) azonosítása csak újabban, a FISH módszer alkalmazása óta vált lehetővé (11). A Mitelman adatbázisban (26) szereplő esetek zömét az utóbbi 2-3 évben írták le, és csak egyetlen olyan esetet regisztráltak, ahol az TEL-AML1 fúziós gén az AML1 gén amplifikációjával társul (24). Az amplifikáció a TEL-AML1 gyári próbával metafázisos kromoszómákon biztonsággal kimutatható, azonosítása azért fontos, mert ez a citogenetikai elváltozás a többi klinikai értéktől független negatív prognosztikai mutató, magas rizikójú (HR) besorolás szerinti kezelést és lehetőleg az első remisszióban történő csontvelőtranszplantációt igényel (28). Mivel az iAMP21 az átlagosnál háromszor nagyobb relapszuskockázattal és szignifikánsan alacsonyabb esemény nélküli túléléssel (EFS; 29\%) jár, a gyermekkori B-sejtes ALL új különálló citogenetikai alcsoportjaként határozták meg (28, 36, 37). Betegünket a harmadik recidíva után veszítettük el a betegség progressziója miatt, transzplantációra alkalmas donora nem volt.

Az I-FISH optimális technikának bizonyult a 9pmikrodeléció detektálására is (3. ábra). G-sávos kariotípus-elemzéssel a betegek 7\%-ában, I-FISH vizsgálattal 20\%-ában azonosítottuk a p16-deléciót. A 9p21 régióban kódolt INK4 fehérjék (p16INK4a, p16INK4b, p14ARF) a sejtciklus szabályozásában szerepet játszó ciklinfüggő kinázgátló csoportba tartoznak. Funkcióvesztésük lehetôvé teszi, hogy a retinoblastoma és a TP53 út ellenőrző pontjain a sejtek génhibával együtt akadálytalanul tovább jussanak és osztódjanak. A p16-deléció ismert humán tumorokban, leukémiákban viszonylag ritka, gyermekkori (elsősorban a T-sejtes) ALL-ben egyike a leggyakoribb rejtett rendellenességeknek. A vizsgált betegeknél a p16-deléció volt a második leggyakoribb rendellenesség, de egyelöre nem elég hosszú a követési idő ahhoz, hogy prognosztikai hatását értékeljük. Az a tény, hogy a deléció hétből öt betegnél más citogenetikai eltérésekkel társult, igazolja azt a feltevést, hogy a deléció olyan másodlagos elváltozás lehet, mely a betegség progressziójában játszik szerepet (18).

$\mathrm{Az}$ eddigi irodalmi adatok a deléció prognosztikai hatásával kapcsolatosan ellentmondásosak (23), ami azzal állhat összefüggésben, hogy a deléciós státusz a sejtek kemoterápiás szerekkel szembeni érzékenységét is befolyásolja $(6,44)$. A deléció gyakran társul hátrányos klinikai adatokkal (magas fehérvérsejtszám, T-immunfenotípus, mediasztinális érintettség), ilyenkor az eseménymentes túlélési ráta az átlagosnál rövidebb (14). A leggyakoribb relapszust a bi-allélikus delécióknál figyelték meg. A deléciót hordozó és HR besorolású betegeknél az alternatív terápia (őssejt-transzplantáció) már az első remisszióban megfontolandó (5).

A gyermekkori leukémiákban viszonylag ritkán (3\%) előforduló Philadelphia (Ph) kromoszóma negatív prognosztikai hatása a gyermekek esetében mérsékeltebb, mint a felnőtteknél. A közelmúltban bevezetett transzlokáció-specifikus kezelés (imatinib-mezilát) kemoterápiával kombinálva egyre hosszabb eseménymentes túlélést biztosít. A Philadelphia kromoszóma-pozitív hétéves gyermeknél a fokozott tirozinkináz-aktivitású BCR-ABL fúziós gén negatív prognosztikai hatását két, a normális vérsejtek képződésében kulcsszerepet játszó tumorszuppresszor gén, a p53 és p16 elvesztése súlyosbította, a beteg életkora pedig enyhítette. A Ph kromoszóma prognosztikai hatása életkorfüggő, a negatív ha- 
tás az életkorral nő, legsikeresebb terápiás eredményt az 1-9 éves életkor közötti betegeknél értek el (3). E beteg ALL-BFM-IC-2002 protokoll HR szerinti kezelésben részesült, jelenleg remisszióban van.

$\mathrm{Az}$ interfázis-FISH vizsgálatot optimálisnak tartjuk a gyermekkori ALL citogenetikai vizsgálatának kiegészítésére. Az I-FISH a hagyományos citogenetikánál érzékenyebb módszer, kevés mintából, osztódó és nem osztódó sejtekből egyaránt lehetővé teszi a specifikus aberrációk azonosítását, alkalmas a G-sávos kariotípus megerősítésére és esetleges korrekciójára is. Más módszerek, mint például a CGH vagy a multicolor-FISH is célravezetőek a rejtett számbeli és szerkezeti rendellenességek feltárására. Csakhogy a multicolor-FISH a mitotikusan aktív sejtek értékelésére ad lehetőséget, a CGH elemzéssel a kisebb kóros populációt a nagyobb, normális populáció maszkírozhatja.

A gyermekkori ALL genetikai eltéréseinek azonosításához az alkalmazott FISH-próbák informatívak voltak. A TEL/AML1-próba segítségével identifikáltunk két jó prognózisú betegcsoportot, a 12;21-es transzlokációt hordozót és a hiperdiploidot, melyek a betegek közel felét érintették. A próba hasznosnak bizonyult egy közismerten jó prognózisú (TEL/AML1-fúzió) és egy negatív prediktív értékű elváltozás (iAMP21) szimultán előfordulásának azonosítására is. Az MLL- illetve a BCR/ABL-próbákkal a rossz prognózisú, hagyományostól eltérő terápiát igénylő genetikai eltéréseket tudtuk kizárni. A CEP9/p16-próbával 6 esetben azonosítottunk rejtett deléciót, a 9p21 tumorszuppresszor régió elvesztése volt a második leggyakoribb rendellenesség. Bár a prognosztikai hatására vonatkozó adatok nem egybehangzóak, a többi klinikai adat függvényében fontos kórjóslati tényező. Az I-FISH vizsgálat kiegészítette és megerősítette a G-sávos citogenetikai eredményeket, a kettő együttes alkalmazása a gyermekkori leukémiák genotípus-meghatározásának hatékony és korszerü eszköze. Ugyanakkor a FISH alkalmazásakor figyelembe kell venni a technika korlátait is: nem az egész kariotípusról kapunk információt, hanem csak célkérdésekre célválaszokat, a kromoszómák közti aberrációk azonosításához elméleti és/vagy előzetes kariotipizálásból származó információk szükségesek.

\section{IRODALOM}

1. Andreasson P, Hoglund M, Bekassy AN, et al. Cytogenetic and FISH studies of a single center consecutive series of 152 childhood acute lymphoblastic leukemias. Eur J Haematol 65:40-51, 2000

2. Anguita E, Gonzalez FA, Lopez J, Villegas A. TEL/AML1 transcript and p16 gene deletion in a patient with childhood acute lymphoblastic leukaemia. Br J Haematol 99:240-241,1997

3. Arico M, Valsecchi MG, Camitta B, et al. Outcome of treatment in children with Philadelphia chromosome-positive acute lymphoblastic leukemia. N Engl J Med 342:998-1006, 2000

4. Bennett JM, Catovsky D, Daniel MT, et al. Proposals for the classification of the acute leukaemias. French-American-British (FAB) co-operative group. Br J Haematol 33:451-458, 1976
5. Calero Moreno TM, Gustafsson G, Garwicz S, et al. Deletion of the Ink4-locus (the p16ink4a, p14ARF and p15ink4b genes) predicts relapse in children with ALL treated according to the Nordic protocols NOPHO-86 and NOPHO-92. Leukemia 16:2037-2045, 2002

6. Chen ZH, Zhang H, Savarese TM. Gene deletion chemoselectivity: codeletion of the genes for p16(INK4), methylthioadenosine phosphorylase, and the alpha- and beta-interferons in human pancreatic cell carcinoma lines and its implications for chemotherapy. Cancer Res 56:1083-1090, 1996

7. Graf Einsiedel H, Taube T, Hartmann R, et al. Prognostic value of p16(INK4a) gene deletions in pediatric acute lymphoblastic leukemia. Blood 97:4002-4004, 2001

8. Haltrich I, Müller J, Szabó J, et al. Donor cell myelodysplastic syndrome developing 13 years after marrow grafting for aplastic anemia. Cancer Genet Cytogenet 142:124-128, 2003

9. Haltrich I, Kost-Alimova M, Fekete G, et al. Multipoint-FISH in childhood T-cell-lineage ALL detects subpopulations that carry $3 q$ trisomies or deletions in the DUTT1/ROBO1 tumor suppressor gene region at 3p12-p13. Cancer Genet Cytogenet 172:54-60, 2007

10. Harbott J, Viehmann S, Borkhardt A, et al. Incidence of TEL/AML1 fusion gene analyzed consecutively in children with acute lymphoblastic leukemia in relapse. Blood 90:4933-4937, 1997

11. Harewood L, Robinson H, Harris R, et al. Amplification of AML1 on a duplicated chromosome 21 in acute lymphoblastic leukemia: a study of 20 cases. Leukemia 17:5475-5453, 2003

12. Harris MB, Shuster JJ, Carroll A, et al. Trisomy of leukemic cell chromosomes 4 and 10 identifies children with B-progenitor cell acute lymphoblastic leukemia with a very low risk of treatment failure: a Pediatric Oncology Group study. Blood 79:3316-3324, 1992

13. Harris RL, Harrison CJ, Martineau M, et al. Is trisomy 5 a distinct cytogenetic subgroup in acute lymphoblastic leukemia? Cancer Genet Cytogenet 148:159-162, 2004

14. Heerema NA, Sather HN, Sensel MG, et al. Association of chromosome arm 9p abnormalities with adverse risk in childhood acute lymphoblastic leukemia: A report from the Children's Cancer Group. Blood 94:1537-1544, 1999

15. Heerema NA, Sather HN, Sensel MG, et al. Prognostic impact of trisomies of chromosomes 10, 17, and 5 among children with acute lymphoblastic leukemia and high hyperdiploidy (> 50 chromosomes). J Clin Oncol 18:1876-1887, 2000

16. Heerema NA, Raimondi SC, Anderson JR, et al. Specific extra chromosomes occur in a modal number dependent pattern in pediatric acute lymphoblastic leukemia. Genes Chromosomes Cancer 46:684-693, 2007

17. Hrusak O, Trka J, Zuna J, et al. Are we ready to curtail testing for TEL/AML1 fusion? Pediatric Hematology Working Group in the Czech Republic. Leukemia 13:981-983, 1999

18. Johansson B, Mertens F, Mitelman F. Secondary chromosomal abnormalities in acute leukemias. Leukemia 8:953-962, 1994

19. Krishna Narla R, Navara C, Sarquis M, Uckun FM. Chemosensitivity of TEL-AML1 fusion transcript positive acute lymphoblastic leukemia cells. Leuk Lymphoma 41:6156-6123, 2001

20. Loh ML, Goldwasser MA, Silverman LB, et al. Prospective analysis of TEL/AML1-positive patients treated on Dana-Farber Cancer Institute Consortium Protocol 95-01. Blood 107:4508-4513, 2006

21. Loh ML, Rubnitz JE. TEL/AML1-positive pediatric leukemia: prognostic significance and therapeutic approaches. Curr Opin Hematol 9:345-352, 2002

22. McLean TW, Ringold S, Neuberg D, et al. TEL/AML-1 dimerizes and is associated with a favorable outcome in childhood acute lymphoblastic leukemia. Blood 88:4252-4258, 1996

23. Mirebeau D, Acquaviva C, Suciu S, et al. The prognostic significance of CDKN2A, CDKN2B and MTAP inactivation in B-lineage acute lymphoblastic leukemia of childhood. Results of the EORTC studies 58881 and 58951. Haematologica 91:881-885, 2006

24. Mikhail FM, Serry KA, Hatem N, et al. AML1 gene over-expression in childhood acute lymphoblastic leukemia. Leukemia $16: 658-668,2002$ 
25. ISCN. An international system for human cytogenetic nomenclature. Eds. Shaffer LG, Tommerup N. Karger S, Basel 2005

26. Mitelman Database of Chromosome Aberrations in Cancer. Eds. Mitelman F, Johansson B, Mertens F. „http://cgap.nci.nih.gov/ Chromosomes/Mitelman", 2007

27. Moorman AV, Richards SM, Martineau M, et al. Outcome heterogeneity in childhood high-hyperdiploid acute lymphoblastic leukemia. Blood 102:2756-2762, 2003

28. Moorman AV, Richards SM, Robinson HM, et al. Prognosis of children with acute lymphoblastic leukemia (ALL) and intrachromosomal amplification of chromosome 21 (iAMP21). Blood 109:2327-2330, 2007

29. Papadhimitriou SI, Polychronopoulou S, Tsakiridou AA, et al. p16 inactivation associated with aggressive clinical course and fatal outcome in TEL/AML1-positive acute lymphoblastic leukemia. J Pediatr Hematol Oncol 27:675-677, 2005

30. Pinkel D, Straume T, Gray JW. Cytogenetic analysis using quantitative, high-sensitivity, fluorescence hybridization. Proc Natl Acad Sci U S A 83:2934-2938, 1986

31. Pui CH, Relling MV, Downing JR. Acute lymphoblastic leukemia. N Eng J Med 350:1535-1548, 2004

32. Pui CH, Evans EW. Treatment of acute lymphoblastic leukemia. N Engl J Med 354:166-178, 2006

33. Raimondi SC, Shurtleff SA, Downing JR, et al. 12p abnormalities and the TEL gene (ETV6) in childhood acute lymphoblastic leukemia. Blood 90:4559-4566, 1997

34. Raimondi SC, Zhou Y, Shurtleff SA, et al. Near-triploidy and neartetraploidy in childhood acute lymphoblastic leukemia: association with B-lineage blast cells carrying the ETV6-RUNX1 fusion, T-lineage immunophenotype, and favorable outcome. Cancer Genet Cytogenet 169:50-57, 2006

35. Ramakers-van Woerden NL, Pieters R, Loonen AH, et al. TEL/ AML1 gene fusion is related to in vitro drug sensitivity for Lasparaginase in childhood acute lymphoblastic leukemia. Blood 96:1094-1099, 2000

36. Robinson HM, Broadfield ZJ, Cheung KL, et al. Amplification of AML1 in acute lymphoblastic leukemia is associated with a poor outcome. Leukemia 17:2249-2250, 2003

37. Robinson HM, Harrison CJ, Moorman AV, et al. Intrachromosomal amplification of chromosome 21 (iAMP21) may arise from a breakage-fusion-bridge cycle. Genes Chromosomes Cancer 46:318-326, 2007
38. Romana SP, Le Coniat M, Berger R. t(12;21): a new recurrent translocation in acute lymphoblastic leukemia. Genes Chromosomes Cancer 9:186-191, 1994

39. Romana SP, Poirel H, Leconiat M, et al. High frequency of $t(12 ; 21)$ in childhood B-lineage acute lymphoblastic leukemia. Blood 86:4263-4269, 1995

40. Schultz KR, Pullen DJ, Sather HN, et al. Risk- and response-based classification of childhood B-precursor acute lymphoblastic leukemia: a combined analysis of prognostic markers from the Pediatric Oncology Group (POG) and Children's Cancer Group (CCG). Blood 109:926-935, 2007

41. Schrappe M, Reiter A, Zimmermann M, et al. Long-term results of four consecutive trials in childhood ALL performed by the ALLBFM study group from 1981 to 1995 . Berlin-Frankfurt-Munster. Leukemia 14:2205-2222, 2000

42. Seeger K, Buchwald D, Peter A, et al. TEL-AML1 fusion in relapsed childhood acute lymphoblastic leukemia. Blood 94:374-376, 1999

43. Seeger K, von Stackelberg A, Taube T, et al. Relapse of TEL-AML1positive acute lymphoblastic leukemia in childhood: a matchedpair analysis. J Clin Oncol 19:3188-3193, 2001

44. Shah SJ, Taub JW, Witt TL, et al. Relationship of p15 and p16 gene alterations to elevated dihydrofolate reductase in childhood acute lymphoblastic leukaemia. Br J Haematol 113:746756, 2001

45. Shurtleff SA, Buijs A, Behm FG, et al. TEL/AML1 fusion resulting from a cryptic $t(12 ; 21)$ is the most common genetic lesion in pediatric ALL and defines a subgroup of patients with an excellent prognosis. Leukemia 9:1985-1989, 1995

46. Sutcliffe MJ, Shuster JJ, Sather HN, et al. Outcome heterogeneity in childhood high-hyperdiploid acute lymphoblastic leukemia. Blood 102:2756-2762, 2003

47. Sutcliffe MJ, Shuster JJ, Sather HN, et al. High concordance from independent studies by the Children's Cancer Group (CCG) and Pediatric Oncology Group (POG) associating favorable prognosis with combined trisomies 4, 10, and 17 in children with NCI Standard-Risk B-precursor Acute Lymphoblastic Leukemia: a Children's Oncology Group (COG) initiative. Leukemia 19:734740,2005

48. Takeuchi S, Seriu T, Bartram CR, et al. TEL is one of the targets for deletion on $12 p$ in many cases of childhood B-lineage acute lymphoblastic leukemia. Leukemia 11:1220-1223, 1997 